ARTIKEL PENELITIAN

\title{
PENGARUH PEMBERIAN MINYAK BUAH MERAH (Pandanus conoideus lam) TERHADAP KADAR GLUKOSA DARAH DAN MALONDIALDEHID SERUM MENCIT YANG DIINDUKSI ALOKSAN
}

\author{
Husnil Kadri ${ }^{1}$, Ezy Julian Jarit ${ }^{2}$, Erlina Rustam ${ }^{3}$ \\ 1. Bagian Biokimia Fakultas Kedokteran Universitas Andalas \\ 2. Mahasiswa Kedokteran Umum Fakultas Kedokteran Universitas Andalas \\ 3. Bagian Farmakologi Fakultas Kedokteran Universitas Andalas \\ E-mail : husnilbiokimia@yahoo.com
}

\begin{abstract}
Abstrak
Tujuan penelitian ini adalah untuk menentukan efek pemberian minyak buah merah (pandanus conoideus lam) terhadap kadar glukosa darah dan malondialdehid (MDA) serum mencit yang diinduksi dengan aloksan. Induksi aloksan ini menyebabkan hiperglikemia yang dapat mencetuskan stres oksidatif. Minyak buah merah yang mengandung banyak antioksidan dapat mengendalikan stres oksidatif yang akhirnya dapat menurunkan kadar glukosa darah dan MDA serum.

Penelitian eksperimental ini menggunakan 15 ekor mencit jantan yang diseleksi secara random. Hewan coba dibagi menjadi 3 kelompok masing-masing terdiri 5 ekor mencit, yaitu; kelompok kontrol negatif yang hanya diberikan makan dan minum, kelompok kontrol positif yang diinduksi aloksan, dan kelompok perlakuan (diberi minyak buah merah oral) yang diinduksi aloksan. Setelah perlakuan hari ke-14, darah mencit diambil untuk diperiksa kadar glukosa darah dan MDA serum.

Hasil penelitian menunjukkan rerata kadar glukosa darah kelompok kontrol negatif adalah 141,20 $\pm 13,10 \mathrm{mg} / \mathrm{dl}$. Rerata kadar glukosa darah kelompok kontrol positif adalah $266,00 \pm 111,10 \mathrm{mg} / \mathrm{dl}$. Rerata kadar glukosa darah kelompok perlakuan adalah 194,80 $\pm 27,00 \mathrm{mg} / \mathrm{dl}$. Rerata kadar MDA serum kelompok kontrol negatif adalah $0,91 \pm 0,10 \mathrm{nmol} / \mathrm{ml}$. Rerata kadar MDA serum kelompok kontrol positif adalah 1,49 $\pm 0,34 \mathrm{nmol} / \mathrm{ml}$. Rerata kadar MDA kelompok perlakuan adalah $0,97 \pm 0,14 \mathrm{nmol} / \mathrm{ml}$. Perbedaan bermakna kadar glukosa darah hanya antara kelompok kontrol negatif dengan kelompok perlakuan ( $\mathrm{p}<0.05)$. Analisis statistik kadar MDA serum menunjukkan terdapat perbedaan bermakna antara kelompok kontrol positif dengan kelompok perlakuan $(\mathrm{p}<0,05)$. Kesimpulan dari penelitian ini ialah minyak buah merah tidak mampu menurunkan kadar glukosa darah pada kelompok perlakuan, tetapi minyak buah merah mampu menurunkan kadar MDA serum pada kelompok perlakuan.
\end{abstract}

Kata kunci: minyak buah merah, glukosa darah, MDA serum, mencit, aloksan 


\begin{abstract}
The objective of this studi was to determine the effect of red fruit oil (pandanus conoideus lam) on blood glucose and serum malondialdehyde in alloxan induced diabetic mice. Hyperglycemia in this mice could lead to oxidative stress. Red fruit oil contains high antioxidants that have capability to control oxidative stress, so blood glucose and serum MDA is reduced.

This experimental study had been carried out to 15 rats (randomized group design) which divided into three group of five rats each, i.e. negative control, positive control (alloxan induced), and the group was treated by alloxan induced which followed by red fruit oil orally for 14 days. The result was analyzed by using one way Anova with confidence interval 95\%.

The result show that blood glucose in negative control was $141.20 \pm 13.10 \mathrm{mg} / \mathrm{dl}$. Blood glucose in positive control was $266.00 \pm 111.10 \mathrm{mg} / \mathrm{dl}$. Blood glucose in the group was treated by alloxan induced which followed by red fruit orally is $194.80 \pm 27.00 \mathrm{mg} / \mathrm{dl}$. The MDA level in negative control group is $0.91 \pm 0.10$ $\mathrm{nmol} / \mathrm{ml}$, positive control group is $1.49 \pm 0.34 \mathrm{nmol} / \mathrm{ml}$, and the group was treated by alloxan induced which followed by red fruit orally is $0.97 \pm 0.14$ $\mathrm{nmol} / \mathrm{ml}$. Blood glucose was significantly different between negative control and treated group ( $\mathrm{p}<0.05)$. Serum MDA was significantly different between positive control group and the group was treated by alloxan induced which followed by red fruit orally $(\mathrm{p}<0.05)$.

The conclusion is red fruit oil cannot reduce blood glucose level in the group was treated by alloxan induced which followed by red fruit orally, but it has capability to quench serum MDA level in this group.

Key word: red fruit oil - blood glucose - serum MDA - mice - alloxan
\end{abstract}




\section{PENDAHULUAN}

Buah merah (pandanus conoideus lam) adalah jenis tanaman pandan-pandanan yang tumbuh liar di wilayah Papua, Papua New Guinea, dan bagian utara Maluku yang menyebar dari daerah pantai hingga pegunungan. Pengamatan epidemiologi pada masyarakat Jayawijaya didapatkan bahwa orang yang telah mengkonsumsi buah merah dalam jangka panjang sangat jarang menderita penyakit kanker, stroke, jantung, diabetes, dan lain-lain. Penelitian Budi dan Paimin (2005) yang dilakukan sejak tahun 2001 membuktikan bahwa buah merah mengandung senyawa aktif yang dapat menangkal senyawasenyawa radikal. ${ }^{(1)}$

Hubungan antara kadar glukosa dengan malondialdehid (MDA) darah telah pernah diteliti oleh Yulistini pada tahun 2001, yang menemukan bahwa kadar MDA pada penderita diabetes mellitus (DM) lebih tinggi daripada orang normal. $^{(2)}$

Peneliti lain, yaitu Winarto pada tahun 2007 telah melakukan penelitian minyak buah merah terhadap aktivitas hipoglikemik glibenklamid dan perubahan gambaran histologis pada pulau Langerhans pankreas. Hasilnya adalah minyak buah merah meningkatkan jumlah, diameter pulau Langerhans, dan efek hipoglikemik glibenklamid pada tikus diabetes. ${ }^{(3)}$

Berdasarkan hasil penelitian di atas, maka penulis ingin mengetahui pula bagaimana pengaruh pemberian minyak buah merah terhadap kadar glukosa dan MDA darah mencit yang diinduksi aloksan.

Tujuan penelitian ini adalah menentukan efek pemberian minyak buah merah terhadap kadar glukosa darah dan MDA serum mencit yang diinduksi oleh aloksan.
Manfaat penelitian ini ialah memberi gambaran tentang efek dari minyak buah merah terhadap pengendalian glukosa darah dan MDA serum pada tikus hiperglikemi. Informasi bagi masyarakat khususnya penderita DM untuk menggunakan buah merah sebagai obat tradisional.

\section{METODE PENELITIAN}

Jenis penelitian ini adalah eksperimental dengan mengggunakan mencit sebagai binatang percobaan. Penelitian dilakukan di laboratorium Biokimia Fakultas Kedokteran Universitas Andalas, pemeliharaan mencit dilakukan di laboratorium Farmasi Fakultas MIPA Universitas Andalas yang berlangsung dari bulan Agustus - September 2009.

Sampel dari penelitian ini adalah mencit sebanyak 15 ekor yang dipilih secara acak yang terdiri mencit jantan dengan berat badan $23-29$ gram. Besar sampel ditentukan dari rumus Fraenkle and Wallen.

\section{Variabel Penelitian}

- Variabel Bebas : Pemberian minyak buah merah.

- Variabel Tergantung: Kadar glukosa dan MDA darah

\section{Definisi Operasional}

1. Mencit hiperglikemi ialah mencit yang mengalami kenaikan kadar glukosa darah melebihi jumlah normal.

2. Minyak Buah Merah olahan buah merah yang berupa minyak dan berkhasiat obat yang diproduksi oleh PT Prima Solusi I Jakarta dengan merek MBM.

3. Aloksan $(2,4,5,6 \quad$ Tetra oksipirimidin 5,6 dioksiurasil) merupakan bahan kimia digunakan untuk menginduksi 
diabetes pada binatang glukosa darah normal $(90-140 \mathrm{mg} / \mathrm{dl})$. percobaan.

Pengukuran kadar glukosa darah dilakukan dengan Gluco- DR dan pada

Dosis aloksan yang digunakan untuk hari terakhir diukur secara enzimatis menginduksi diabetes tergantung kepada spesies percobaan. Penelitian ini menggunakan aloksan dengan dosis $150 \mathrm{mg} / \mathrm{kg}$ BB secara intra peritoneal.

\section{Persiapan Hewan Percobaan}

Sebelum perlakuan, 15 ekor mencit terlebih dahulu diaktimatisasi dalam kondisi laboratorium selama satu minggu dengan diberi makan yang cukup. Pada hari terakhir, diukur kadar glukosa darah puasa. Mencit yang dengan alat Microlab 300. Kadar MDA serum diukur dengan metoda Placer, Cusman, and Johnson dengan uji Thio Barbituric Acid (TBA) dan pembacaannya menggunakan Spectronic 21.

\section{Perencanaan Dosis}

- $\quad$ Aloksan $150 \mathrm{mg} / \mathrm{kg} \mathrm{BB}^{(4)}$

- Minyak buah merah $0.6 \mathrm{ml} /$ $\operatorname{kgBB}^{(5)}$

\section{$\underline{\text { Alur Penelitian }}$}

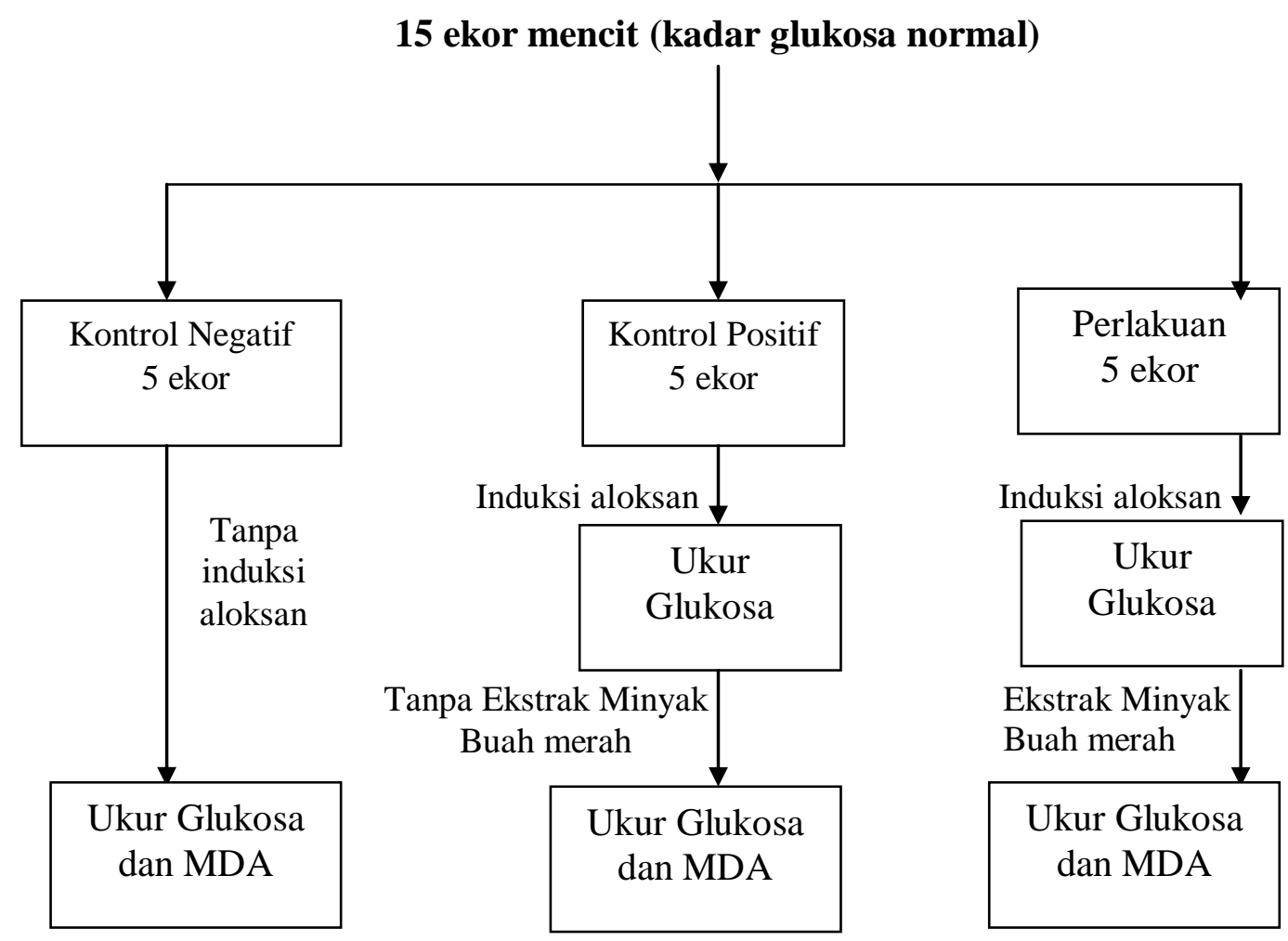


Perlakuan pada Hewan Coba

15 ekor mencit yang

mempunyai kadar glukosa darah puasa normal dibagi menjadi tiga kelompok, yaitu :

1. Kelompok I (Kontrol negatif) mencit tidak diinduksi aloksan dan tidak diberi minyak buah merah, hanya diberi makan dan minum.

2. Kelompok II (kontrol positif) mencit diinduksi aloksan secara intraperitoneal dengan dosis $150 \mathrm{mg} / \mathrm{kg} \mathrm{BB}$ dan tidak diberi minyak buah merah.

3. Kelompok III (Perlakuan) tikus diinduksi aloksan secara intraperitoneal dengan dosis
$150 \mathrm{mg} / \mathrm{kg}$ BB dan diberi minyak buah merah secara oral.

\section{Pengolahan dan Analisa Data}

Data yang diperoleh dianalisis dengan SPSS 12,0. Uji hipotesis menggunakan uji one way anova berpasangan yang didahului oleh uji normalitas pada derajat kepercayaan 95\%. Jika hasil uji $=\mathrm{p}<0,05$ maka dilanjutkan dengan analisis post hoc.

\section{HASIL}

Hasil yang diperoleh pada pengukuran kadar glukosa darah secara enzimatis dan MDA serum adalah sebagai berikut :

Tabel 1. Kadar glukosa dan MDA darah mencit pada ke tiga kelompok penelitian

\begin{tabular}{|c|c|c|c|}
\hline No & Kelompok & $\begin{array}{c}\text { Glukosa Darah } \\
\text { (mg/dl) }\end{array}$ & $\begin{array}{c}\text { MDA Serum } \\
(\mathbf{n m o l} / \mathbf{m l})\end{array}$ \\
\hline 1 & Kontrol negatif (K-1) & 128 & 0,99 \\
\hline 2 & Kontrol negatif (K-2) & 136 & - \\
\hline 3 & Kontrol negatif $(\mathrm{K}-3)$ & 152 & - \\
\hline 4 & Kontrol negatif (K-4) & 132 & 0,93 \\
\hline 5 & Kontrol negatif (K-5) & 158 & 0,80 \\
\hline 6 & Kontrol positif $(K+1)$ & 253 & 1,25 \\
\hline 7 & Kontrol positif $(\mathrm{K}+2)$ & 374 & 1,95 \\
\hline 8 & Kontrol positif $(\mathrm{K}+3)$ & 159 & 1,73 \\
\hline 9 & Kontrol positif $(\mathrm{K}+4)$ & 386 & 1,16 \\
\hline 10 & Kontrol positif $(\mathrm{K}+5)$ & 158 & 1,36 \\
\hline 11 & Perlakuan (P1) & 183 & 0,98 \\
\hline 12 & Perlakuan (P2) & 233 & 1,14 \\
\hline 13 & Perlakuan (P3) & 212 & 0,81 \\
\hline 14 & Perlakuan (P4) & 179 & 0,93 \\
\hline 15 & Perlakuan (P5) & 167 & - \\
\hline
\end{tabular}

Hasil uji normalitas menunjukkan bahwa distribusi semua kelompok data adalah normal $(p>0,05)$. Rerata kadar glukosa darah kelompok kontrol negatif adalah $141,20 \pm 13,10 \mathrm{mg} / \mathrm{dl}$. Rerata kadar glukosa darah kelompok kontrol positif adalah $266,00 \pm 111,10 \mathrm{mg} / \mathrm{dl}$. Rerata kadar glukosa darah kelompok perlakuan adalah 194,80 $\pm 27,00 \mathrm{mg} / \mathrm{dl}$. Berdasarkan analisa statistik Anova pada ketiga kelompok penelitian dengan derajat kepercayaan 95\% didapatkan $\mathrm{p}=0,04$ $(\mathrm{p}<0.05)$. Hal ini berarti paling tidak terdapat perbedaan kadar glukosa darah secara bermakna pada dua kelompok. Oleh sebab itu analisa statistik dapat dilanjutkan dengan post hoc test. Hasilnya dapat dilihat pada tabel dibawah ini. 
Tabel 2. Tingkat kemaknaan hasil Post hoc Tamhane's T2 terhadap kadar glukosa darah mencit

\begin{tabular}{llcc}
\hline \multicolumn{1}{c}{ Kelompok } & \multicolumn{1}{c}{ Kelompok } & $\begin{array}{c}\text { Perbedaan } \\
\text { Rerata }\end{array}$ & Probabilitas \\
\hline Kontrol Negatif & $\begin{array}{l}\text { Kontrol Positif } \\
\text { Perlakuan }\end{array}$ & $-124,80$ & 0,18 \\
& & $-53,60$ & 0,02 \\
Kontrol Positif & Kontrol Negatif & 124,80 & 0,18 \\
& Perlakuan & 71,20 & 0,54 \\
Perlakuan & Kontrol Positif & $-71,20$ & 0,54 \\
& Kontrol Negatif & 53,60 & 0,02 \\
\hline
\end{tabular}

Berdasarkan uji post hoc pada Tabel.2. tampak bahwa perbedaan bermakna hanya antara kelompok kontrol negatif dengan kelompok perlakuan $(\mathrm{p}<0.05)$, sedangkan antara kelompok kontrol positif dengan kelompok kontrol negatif dan kelompok kontrol positif dengan kelompok perlakuan tidak ada perbedaan yang bermakna ( $p>0,05)$.

Rerata kadar MDA serum kelompok kontrol negatif adalah $0,91 \pm$ 0,10 $\mathrm{nmol} / \mathrm{ml}$. Rerata kadar MDA serum kelompok kontrol positif adalah $1,49 \pm 0,34 \mathrm{nmol} / \mathrm{ml}$. Rerata kadar
MDA kelompok perlakuan adalah 0,97 $\pm 0,14 \mathrm{nmol} / \mathrm{ml}$. Uji homogeneity of variances menunjukkan bahwa terdapat perbedaan varian antara kelompok yang dibandingkan, sehingga uji Anova tidak bisa dilakukan. Sebagai gantinya dilakukan uji Kruskal-Wallis. Pada uji ini ditemukan paling tidak terdapat perbedaan kadar MDA serum secara bermakna pada dua kelompok $\mathrm{p}=0,02$ $(\mathrm{p}<0,05)$. Oleh sebab itu analisa statistik dapat dilanjutkan dengan post hoc test.

Hasilnya dapat dilihat pada tabel dibawah ini.

Tabel 3. Tingkat kemaknaan hasil Post hoc dengan Mann-Whitney terhadap kadar MDA serum mencit

\begin{tabular}{llc}
\hline \multicolumn{1}{c}{ Kelompok } & \multicolumn{1}{c}{ Kelompok } & Probabilitas \\
\hline Kontrol Negatif & Kontrol Positif & 0,03 \\
& Perlakuan & 0,59 \\
Kontrol Positif & Kontrol Negatif & 0,03 \\
& Perlakuan & 0,01 \\
Perlakuan & Kontrol Positif & 0,01 \\
& Kontrol Negatif & 0,59 \\
\hline
\end{tabular}


Berdasarkan uji post hoc pada Tabel.3. tampak bahwa terdapat perbedaan bermakna antara kelompok kontrol negatif dengan kelompok kontrol positif dan kelompok kontrol positif dengan kelompok perlakuan $(\mathrm{p}<0.05)$, sedangkan antara kelompok kontrol negatif dengan kelompok perlakuan tidak didapatkan perbedaan yang bermakna $(p>0,05)$.

\section{PEMBAHASAN}

Rerata kadar glukosa darah pada ketiga kelompok terlihat sangat berbeda (Tabel.1), tetapi pada uji statistik hanya antara kelompok kontrol negatif dengan kelompok perlakuan yang terdapat perbedaan bermakna (Tabel.2). Padahal aloksan merupakan bahan kimia yang bisa menginduksi terjadinya diabetes pada binatang percobaan. Aloksan lazim digunakan karena cepat menimbulkan hiperglikemia yang permanen dalam waktu 2 sampai 3 hari, karena aloksan secara selektif merusak sel-sel beta pulau langerhans dalam pankreas yang mengsekresikan insulin. ${ }^{(4)}$ Pembentukan senyawa oksigen reaktif oleh aloksan dalam bentuk tereduksinya melalui siklus redoks membentuk radikal - radikal superoksida. Melalui siklus redoks membentuk radikal - radikal hidroksil yang sangat reaktif yang dapat menyebabkan kerusakan sel-sel beta pankreas secara cepat. ${ }^{(6)}$

Ketidaksamaan ini mungkin disebabkan oleh jumlah mencit dalam tiap kelompok masih kurang, meskipun sebelumnya sudah dihitung berdasarkan rumus Fraenkle and Wallen. Kemungkinan lain adalah adanya kadar glukosa darah mencit dalam kelompok kontrol positif (yaitu $\mathrm{K}+3$ dan $\mathrm{K}+5$ ) yang tidak berbeda dari kelompok kontrol negatif, seharusnya kedua mencit ini diganti dengan mencit lain yang kadar glukosa darahnya mendekati kadar rerata kelompok positif.

Tingginya kadar MDA pada kelompok kontrol positif (Tabel.3) disebabkan oleh karena hiperglikemia pada diabetes melitus menyebabkan pembentukan radikal bebas. Hiperglikemia meningkatkan produksi radikal bebas melalui tiga mekanisme, yaitu peningkatan aktivitas jalur poliol, glukoautooksidasi, dan glikasi protein. ${ }^{(7)}$ Pembentukan senyawa oksigen reaktif tersebut dapat meningkatkan modifikasi lipid, DNA, dan protein pada berbagai jaringan. Modifikasi molekuler pada berbagai jaringan tersebut mengakibatkan ketidakseimbangan antara antioksidan protektif (pertahanan antioksidan) dan peningkatan produksi radikal bebas. Hal ini merupakan awal kerusakan oksidatif yang dikenal sebagai stres oksidatif. Dampak negatif pada membran sel akan terjadi reaksi rantai yang disebut peroksidasi lipid. Akibat akhir dari rantai reaksi ini adalah terputusnya rantai asam lemak menjadi berbagai senyawa yang toksik terhadap sel, antara lain Malondialdehid (MDA), etana, dan pentana. ${ }^{(8)}$

Uji statistik pada kelompok perlakuan didapatkan kadar MDA serum yang tidak berbeda dengan kelompok kontrol negatif. Kadar MDA serum kelompok perlakuan yang lebih rendah dibanding kelompok kontrol positif disebabkan karena kandungan senyawa antioksidan serta lemak pada buah merah sebagai salah satu alternatif untuk membantu memperbaiki daya tahan tubuh. Daya tahan tubuh ini disebabkan oleh kandungan kimiawi dari minyak Buah Merah misalnya dengan adanya kandungan Betakaoten dan Tokoferol serta senyawa minyak lemak jenuh maupun tak jenuh. ${ }^{(9)}$ 
Minyak buah merah mengandung karotenoid, betakaroten, alfa tokoferol, asam oleat, asam linoleat, asam linolenat dan dekanoat, omega 3 dan omega 9. Buah merah juga mengandung banyak kalori untuk menambah energi, kalsium, serat, protein, vitamin $\mathrm{B} 1$, dan vitamin $\mathrm{C}$. Menurut hasil analisa yang dilakukan Institut Pertanian Bogor (IPB), buah merah ternyata memiliki kandungan karotenoid dan tokoferol dalam kadar yang tinggi. Total karotenoid pada buah merah segar adalah 34,000 ppm, sementara pada sari Buah Merah 8,600 ppm. Total Tokoferol pada buah merah segar adalah 133,000 ppm sedangkan pada sari buah merahnya 17,000 ppm. Selain karotenoid dan tokoferol, sari buah merah juga mengandung asam lemak jenuh seperti asam laurat, palmitat, stearat, dan asam lemak tak jenuh seperti asam palmitoleat, oleat, linoleat, omega-3, dan lain-lain. Secara ringkas buah merah mengandung: antioksidan (karotenoid, tokoferol), asam lemak jenuh dan tak jenuh, serat dan kalsium. ${ }^{(1)}$

\section{KESIMPULAN}

Kesimpulan dari penelitian ini ialah minyak buah merah tidak mampu menurunkan kadar glukosa darah pada kelompok perlakuan, tetapi minyak buah merah mampu menurunkan kadar MDA serum pada kelompok perlakuan ini.

\section{SARAN}

1. Diperlukan penelitian lebih lanjut terhadap minyak buah merah yang bermanfaat sebagai antioksidan.

2. Diperlukan penelitian dengan jumlah sampel yang lebih banyak sehingga di peroleh hasil yang lebih bermakna antara kelompok kontrol positif dengan kelompok perlakuan.

\section{KEPUSTAKAAN}

1. Budi, IM; Paimin, FR. Buah Merah. Penebar Swadaya. Jakarta. 2005.

2. Yulistini. Gambaran Kadar Malondialdehid Darah Berdasarkan Kadar Glukosa Darah pada Penderita Diabetes Mellitus. Skripsi. Fakultas Kedokteran Universitas Andalas. 2001.

3. Winarto. Pengaruh Minyak Buah Merah (Pandanus conoideus lam) Terhadap Gambaran Sel $\beta$ Pankreas dan Efek Hipoglikemik Glibenklamid pada Tikus Jantan galur wistar Diabetik. 2007. Diakses 18 Desember 2008 dari http://puspasca.ugm.ac.id

4. Suharmiati. Pengujian Bioaktivitas Anti Diabetes Mellitus Tumbuhan Obat. Cermin Dunia Kedokteran 2003; 140. Diakses 6 Juni 2009 dari http://kabefarma.com

5. Munim, A. Uji Hambat Tumorigenesis Minyak Buah Merah Terhadap Tikus Putih Betina Yang Diinduksi 7,12 DMBA.2006. Diakses 6 Juni 2009 dari http://indonesiaindonesia.com

6. McLetchie. Alloxan Diabetes, A Discovery, Albeit A Minor One. JR Coll Physician Edinb 
2002;32:1. Diakses 2007 dari http://.rcpe.ac.uk/transplantscotl and.

7. Bartosikova, L; Necas,J; Suchy,V; et al. Monitoring of antioxidative Effect of Morine in Aloxan-Induced Diabetes Melitus in the Laboratory Rat. ACTA VET. BRNO 2003, 72: 191-200.
8. Suryohandono, P. Oksidan, Antioksidan, dan Radikal Bebas. Buku Naskah Lengkap Simposium Pengaruh Radikal Bebas Terhadap Penuaan dalam Rangka Lustrum IX FKUA 7 September 1955-2000. 2000.

9. Yahya, M. Buah Merah (Pandanus conoideus lam). 2006. Diakses 19 Desember 2008 dari http://www.buahmerah.com 